\title{
Socialism and Indian Economic Policy ${ }^{*}$
}

\author{
PADMA DESAI \\ Russian Research Center, Harvard University \\ and \\ JAGDISH BHAGWATI \\ Massachusetts Institute of Technology
}

\begin{abstract}
Summary. - This paper examines the interaction of socialist ideas and doctrines with Indian economic policy-making in the last three decades. It concludes with an analysis of the differences between ex-ante aspirations and the ex-post outcomes in regard to these socialist objectives.
\end{abstract}

Socialist ideas have significantly influenced the formulation of the means and objectives of Indian economic policies. This has happened in two distinct ways: via the impact of external, socialist ideologies on the economic and political notions held by élite groups influencing policy-making in India; and via the political constraints imposed on the dominant Congress Party by the relative strength of the left, and the relative weakness of the right, parties in the spectrum of Indian politics. Any serious analysis of the evolution of economic policy in India, the particular combination of policy instruments and objectives characterizing it, and the nature of the outcome in terms of the fulfilment or frustration of the apparent objectives, must therefore address itself to the interaction of socialist doctrines with it. $1^{\dagger}$

\section{THE IMPACT OF SOCIALISM ON POLICY FRAMEWORK}

Two dominant, socialist influences on serious economic thinking during the period of the struggle for independence were the example of Soviet communism ${ }^{2}$ and the Fabian Society's deliberations on the nature of the socialist society and the gradualist approach thereto, ${ }^{3}$ the latter clearly exercising a powerful impact through the large numbers of the Indian élite that were processed through the English educational institutions prior to Indian independence in 1947.4

Nearly all traditional socialist doctrines lead in the direction of public ownership of the means of production, and (failing total control of the means of production) they equally point in the direction of public ownership of the 'key' sectors of production. The specific shape given to these doctrines in the Indian context however was in the Fabian-type gradualism which characterized the transition to public ownership, in toto and of the key sectors. Thus, nationalizations of existing capital stock were de facto ruled out. Rather, the government, through successive five-year plans, sought to increase the share of the public sector in total investment, expecting at the end of such a sustained effort to raise the government's share of the capital stock to a dominant level: the approach to the Marxist goal of public ownership was thus to be asymptotic. ${ }^{5}$ Similarly, on the problem of key sectors, the "commanding heights' of the economy, defined to include steel and heavy industry, the successive Industrial Policy Resolutions of the government again focused on reservation of these areas to public sector investment rather than on the take-over of existing private sector concerns (as in the case of the Tata Steel). 6

While, therefore, the impact of Fabian gradualism, as also the pragmatic sense that the private sector be allowed to make a contribu-

* Presented at the Christmas 1974 meetings of the American Economic Association and the Association for Comparative Economic Systems.

$\dagger$ See Notes at end of article. 
tion to industrialization in the medium-run while the economy was being transformed into one dominated by the public sector, was evident in the policies just detailed, the impact of the Soviet example was to be manifest in three other areas of economic policy which were to set the stage equally significantly for India's economic performance. ${ }^{7}$ First, the possibility of a shift to heavy industry, within the industrialization programme, was to characterize the Second Five-year Plan (1956-61), and was to continue into the Third Plan until the shift into the Green Revolution strategy began towards the end of the Third Plan. 8 Next, the industrialization programme was to become subject to targeting for many industries and to detailed industrial licensing, extending to product-level attention and regulation, over the entire, modern, large-scale non-agricultural sector-the key role in elevating this approach to a sacrosanct principle being played by the Industrial Regulation Act of 1961.9 Finally, the notion that an overview of the economy be taken, and the main thrust of the economy be defined and given shape therein, led along the Soviet lines to the Five-year Plan formulation: though, here again, the First Plan was a rather loosely-defined exercise adding up largely to social-overhead projects and broad fiscal policy objectives, much along the lines of the Harrod-Domar, flow-model framework, and it was only with the Second Plan that the rather tighter, consistency approach, closer to the Soviet-type planning framework, was adopted and investment allocations were more specifically set out. 10

It might be noted that these major contours of the Indian economic policy framework, influenced by socialist thinking of the Fabian type and by the Soviet practice of socialism, were reinforced by other factors on the scene and, indeed, in many instances reinforced one another. Thus, the Second Plan was to precipitate a foreign exchange crisis in 1956-7, which led to the view that foreign exchange should be preserved carefully by administrative regulation; this, in turn, strengthened the impulse to license and to target capacity creation and output along Soviet lines. Similarly, the expanded role of heavy industry with the Second Plan reinforced the relative expansion of the public sector share of investment; it was difficult to persuade the private sector to invest in heavy industry and the public sector had to step in, quite aside from ideological reasons, to undertake these investments. To take yet another example, the expansion of the public sector was also seen by many as yielding an economic externality in terms of added savings formation. Tax policy was likely to be constrained by political factors and the public sector concerns could more readily raise the 'revenue' and savings to lead to greater capital formation through suitable price policy. Again, the industrial and import licensing machinery was not merely directed at the regulation of the composition of industrial production and investment, but was also considered necessary as an instrument for preventing the concentration of wealth and economic power within a limited number of large Industrial Houses in the private sector.

Socialist thinking and precept influenced not merely the policy-making élite in the Congress Party that has virtually dominated the political scene since independence in 1947; it also constrained the flexibility of the Congress Party for moving in other directions, because the more doctrinaire left-wing political parties pulled the Congress Party's programmes in the socialist direction, at least at the ex-ante level of party resolutions and declared intentions. Indeed, within the Congress Party itself, the left wing has exerted strong pressure in the direction of socialist programmes, and the party split into the Old and the New Congress, along these lines, with the New Congress of Mrs. Indira Gandhi castigating the Old, and now increasingly defunct, Congress as right-wing and reactionary. In fact, the political ethos of the country has made 'socialism' a good word that wins elections, unlike in the United States where, as Galbraith discovered in the last national election, it is a word that loses elections. Whether, however, the socialist content of the programmes has been real or illusory, and whether the programmes when socialist have been successful or compromised, is a separate issue, undoubtedly of importance, which we defer till later in this paper.

\section{RELATED DIMENSIONS OF POLICY FRAMEWORK}

Finally, it is necessary to complete the picture of the economic policy framework in India, as she entered the planning period in 1949-50 and through the decade of the 1950s and much of the 1960 s, by sketching in some additional dimensions.

Raising minimum incomes through growth. It is clear that, from an early stage, Indian policy thinking was dominated by the view that the distribution of income could not be significantly affected by distributive measures of a 
fiscal type. Partly this view reflected the feeling, based on earlier statistical studies, that, short of communist societies, the Lorenz-curve type of distribution measures indicated that very little could be changed by way of the distribution of income in different societies. More importantly, this view was reinforced by the view that a long-lasting effect on the incomes of the poor was possible only if the economy was geared to raising incomes, investment and hence jobs for the underemployed as rapidly as possible: the alternative policy of using savings to redistribute consumption immediately, as distinct from investing them, was considered a short-term, myopic policy for a country with the staggering problem of poverty that India had, and was to be used only moderately to provide public consumption, as discussed below.

Thus Indian economic policy was essentially set up in the context of a growth model aimed at achieving a rapid rate of growth, reaching increasing levels of domestic saving through appropriate tax effort (as evidenced by the growth of taxes as a percentage of GNP and by the share, at over a quarter during the 1960 s, of the public sector in domestic savings formation), and supplementing them during the transition with foreign resources to reach required investment levels. ${ }^{11}$ It was optimistically hoped that the economy would then grow to reach self-sustained growth within a perspective of up to 25 years, and that a serious dent would have been made in the problem of ameliorating poverty on a sustained basis.

External capital. The policy assumption thus, at least by the Second Plan, was that the country would utilize foreign assistance, 12 using 'aid to end aid'. And, indeed, the utilization of external assistance from all sources, Western and Soviet-bloc, was to run at significant levels from 1956-7 down to the mid1960 s, even though, on a per capita or share-ofGNP basis, India was among the least-favoured recipients of aid by virtue of its size. ${ }^{13}$ As regards private foreign investment, attitudes were coloured by the Indian colonial experience: such investment was regulated closely, directed to specific areas, and left-wing opinion was always critical of it, even though, given India's size, there was no reason to fear that such investment could ever have arrived at levels which would threaten the country with the unenviable status of a banana republic.

Expansion of public consumption. Another dimension of the economic programmes, defining the distributional content of the Plans, was provided by educational and health expendi- tures. These were intended to supplement the growth of private consumption as the growth mechanism led to more jobs and more incomes for the poor. While, however, these expenditures were built into all Plans, they were not to be the intended focus of a poverty-elimination strategy until the early 1970 s. ${ }^{14}$

Land reform. Perhaps the most-discussed, but the least successful, programmes related to land reform. In a country shot through with a large variety of land tenure systems, there were several dimensions on which land reform could be sought, both on distributional and on efficiency grounds. Absentee landlordism (under the notorious Zamindari system) was made illegal in the north, while security of landholding for the tenant was legislated for in other areas (such as in Gujerat and Maharashtra) with notable success. But efforts at imposing land ceilings and at promoting co-operative farming, two further components of land reform policy in India, were to fail to take root, as we shall discuss presently.

The resulting Indian policy framework through the 1950 s and most of the 1960 s can then be characterized, from the standpoint of socialist precept and notions, as having the following dimensions:

(i) an increasing share of public investments, at over half the share in the total at the outset of the planning process;

(ii) an increasing public share in the capital stock of 'key' industrial sectors such as heavy industry, resulting from a fairly strict (though not total, in practice) reservation of such sectors for public sector investment;

(iii) a definite denial of nationalization of existing capital stock as the means to increasing public ownership;

(iv) the use of substantial targeting, and of far more comprehensive industrial (and import) licensing, to control and direct the level and composition of industrial production and investment at product-level detail;

(v) the related attempt at using licensing to prevent the concentration of industrial wealth and power within a small number of families and groups;

(vi) a development strategy aimed at raising investments and jobs as rapidly as domestic fiscal effort and external assistance would permit, with only moderate use of resources to provide public consumption (health and education, in the main) by way of direct redistribution for ameliorating poverty in the short run;

(vii) an investment-composition strategy which implied both industrialization and, within it, a substantial Soviet-style expansion of 
heavy industry-turning on its head the traditional, Western economic notions that heavy industry should come in the later, rather than the earlier, process of industrialization; and

(viii) an agricultural strategy, whose major components were modest land reforms aimed eventually at (a) security of tenancy, (b) abolition of absentee landlordism, (c) land ceilings to reduce concentration of land ownership and (d) co-operative farming and marketing, plus land extension, irrigation and community development programmes-excluding therefore any radical nationalization of land for state farming or redistribution to the landless labourers.

It is perhaps useful also, in the spirit of Indian philosophy, to characterize the socialist dimensions of the Indian policy framework by what they were not. State ownership did not imply workers' control over management or even their significant participation therein: the Yugoslav form of socialism was not an inspiration for Indian socialists on any significant scale. Nor were the socialist arguments of the Lange-Lerner variety, which so greatly dominated the economic debate among the opponents of socialism and the proponents of socialism such as Durbin, of any real import to Indian policy-makers or intellectuals. The Feldman-Mahalonobis-type structuralist arguments on the rational composition of investment that culminated in optimal-growth theory were far more influential than the rationalprice-policy implications of the Lange-Lerner variety.

The resulting policy framework was clearly of a mixed-economy type, with the modern and growing non-agricultural sectors subject to growing public investments and to extensive licensing and control of private investments and production, while the agricultural sector-still contributing half of the net domestic productwas subject only to comparatively modest attempts at control and/or radical transformation of the prevalent land tenure systems. This policy framework was considered by most observers at the time to be socialist in its main thrust: and indeed it was influenced significantly, in its conception, by socialist precepts and example, as we have already noted.

\section{III. $E X-A N T E$ ASPIRATIONS AND EX-POST PERFORMANCE}

In fact, the combination of an Anglo-Saxon democratic framework and the socialist orientation of India's economic programmes was taken by many Western commentators of liberal persuasion as making the Indian programme an important and desirable enough rival to the Chinese communist model. This favourable perception was to change during the mid-1960s as the socialist elements in the Indian policy framework came increasingly to be contrasted rather with the ideologically-more-attractive developmental strategies of less neutral countries such as Pakistan and quasi-satellites such as South Korea. Moreover, it was to change also during the early 1970s, but from the opposite perspective as détente with China made Sinology respectable on the mainland United States and as the widespread, uncritical condemnation by armchair Sinologists of the Chinese developmental model was replaced by enthusiastic approbation by jet-setting Sinologists now permitted to peek at the great Chinese experiment.

While, therefore, the Indian policy framework had been oversold earlier, and was later to be undersold, largely as a reflection of Western ideological concerns and intellectual fashions, there is little doubt that its performance during the last two decades has also raised serious doubts about its efficacy and desirability.

In particular, India's rates of accumulation and growth since the mid-1960s have been disappointing, in relation to her past performance, her plans, as also to the performance of many LDCs of diverse sizes and ideological persuasions. At the same time, an increasing number of studies of income distribution in the country suggest strongly that the bottom deciles have not improved their consumption levels since planning began and may, in fact, have become worse off. ${ }^{15}$ The framework of Indian economic policies has therefore been called into question on several dimensions, from the viewpoints of both the capitalist objective of efficiency and the socialist objective of equity. However, we will focus our analysis here on the socialist aspects of India's performance.

1. As the Indian economy has evolved, it has become fairly evident that the abovedescribed mix of policies, addressed to the public and private sectors, has produced essentially a rentier, rather than a socialist (or capitalist) society.

2. The extent of controls over private production and investment in the modern, largescale industrial sector, has long exceeded that justified by any economic rationale. It has to be seen rather as a pseudo-socialist policy which, in fact, creates sheltered markets for entrepreneurs who earn rents on their licences and, 
in the ultimate political analysis, share them increasingly with the party in power. In fact, the licensing machinery, for distributing imports and scarce materials, has not even succeeded in checking the growth of concentrated economic power by the large Industrial Houses. At the same time, it has become evident that the price and distributional controls are generally used to buttress non-proletarian interests. For example, of the small number of produced and price-controlled cars, a specific quota goes to government officials who thereby are assigned the high premia that the new cars fetch in the market. The licensing mechanism produces, at best, redistribution essentially outside of the poverty sector-from the rich to the not-so-rich-and generates considerable economic inefficiency which, in reducing the productivity of investment, compromises the strategy of rapid growth to provide increasing jobs to the poor. 16

3. The expansion of the public sector, in turn, has raised serious questions. The objective of expanding the public sector has indeed been adhered to, more or less; indeed, as we shall presently discuss, even nationalizations have been increasingly undertaken, contrary to the early declarations of policy. But the public sector has not generated the expected surpluses for investment and growth. And their management has suffered from the constraints imposed by their bureaucratic structure and the absence of any ultimate penalty for inefficiency-much as the private sector's efficiency has been impaired, though not to the same degree (given the profit motive), by the creation of sheltered markets through the comprehensive licensing system. The Indian system of parliamentary control has also had the effect of constraining further the exercise of initiative, and the consequent ability to survive short-term mistakes in the pursuit of long-term efficiency, on the part of the management which, in any case, was likely to be risk-averting owing to its heavily-bureaucratic origins. 17

4. While therefore the policies in the nonagricultural, modern sector have deployed socialist-type instruments (e.g., strict licensing of the private, and expansion of the public, sectors), the net outcome has been rather to create a rentier society, with its attendant economic inefficiencies, and a political use of these instruments generally to redistribute incomes within groups distinctly above the poverty line and, only fractionally, to groups below that line.

5. The corresponding lag in pushing land reforms has also been quite notable. It appears that, in the agricultural sector, the land reform legislation has not managed to affect significantly the concentration of land ownership. 18 The benefits of the Green Revolution again seem to have accrued mainly to the larger farmers, with the cheap fertilizers and credit going principally to them rather than to the smaller farmers, and with the landless labour finding its real wages inadequately responsive to the increased productivity of agriculture. ${ }^{19}$

Accumulating evidence, and growing perception, regarding these sharp contrasts between ex-ante aspirations and ex-post realities have naturally raised serious questions among Indian intellectuals about the relationship of the class structure in India to the composition of its political élite and formulation of Indian economic policy, thus raising to the forefront of even neoclassical policy analysis the traditionally neo-Marxist concerns.

The witticism that India's socialist pattern was little more than socialist patter now elicits more than mirth; it is the starting point for serious and systematic reflection on the directions that Indian economic policy and performance can be expected to take. The Indian economist, Raj Krishna, has aptly described the central tendency of Indian policy as 'firstround' socialism: ostensibly socialist measures which wind up being aborted or subverted in execution.

Few intellectuals in India now believe that under the existing political set-up, with a ruling Congress Party still heavily dominated by the urban middle class, large-scale entrepreneurs and landed interests, there can be any real moves from a socialist platform to a socialist reality. This is not a political party with a clear ideological commitment like Lenin's Bolsheviks or Mao's communists; and its professed commitment to socialist notions is increasingly seen to be one of political convenience rather than convictions.

Thus, the recent nationalizations, especially of banking in 1969, were timed so as to assist the (New) Congress Party in consolidating its political position, rather than out of socialist convictions, the increased trend towards such 'conspicuous' acts of socialism being designed essentially to deflect attention from the lack of genuine progress in distributional and growth objectives in the economy. Paradoxically, therefore, the cosmetics of socialism have been increasingly used, unlike in the Nehru era (when pragmatism largely reflected economic necessity rather than political expediency), as the economic programmes are increasingly seen to lack any real, socialist content. 
Perhaps such an outcome, from a socialist viewpoint, was inevitable. Unlike the Marxistcommunist tradition, which imparts a strong ideological basis for revolutionary struggle and fairly clear objectives to which such a struggle can be addressed, the English socialist tradition (which most Indian intellectuals, including Nehru, inherited) is strictly empirical and nonideological. ${ }^{20}$ Such a tradition surely ran the risk, both of degenerating, over time, into socialist patter, without a concrete programme being executed by an ideologically-inspired cadre of socialists, and, indeed, of being captured and turned into an instrument of bourgeois classes pursuing their own interests behind a socialist screen.

In fact, one might cynically predict that, if the economic difficulties of the present government intensify-as they well might, with the government committed to the rentier framework in the modern, non-agricultural sector for political expediency and with the agricultural expansion thanks to the Green Revolution in jeopardy largely (though not exclusively) due to the exogenous shock of the oil crisis-there could follow a series of acts of apparent socialism to maintain the image of progressivity in the spectrum of ideas on the Indian scene. And, qua policy economists, one might well argue then, cynically indeed, that the best thing for economists, in this type of set-up, would be to work out a number of such conspicuous acts of socialism which can be pulled out, periodically, to enable the government to maintain its socialist image, but making sure that they are not economically expensive! ${ }^{21}$ The policy of bank nationalization in 1969 was precisely such a no-loss type of socialist measure which won the Congress Party some more years in office; but the nationalization of wholesale wheat trade in 1973 was an economic disaster and, to its credit, the government decisively backtracked from this decision. 22 Whether the advisers to the present régime will be able to walk this tightrope of bourgeois policies in a socialist framework for much longer, and with minimal damage to the economy, is a question to which there are no obvious answers.

\section{NOTES}

1. It should be emphasized that, in turn, the course of economic policy and performance in India has also influenced socialist thinking among the intellectuals.

2. Among the dominant nationalist leaders who articulated extensively on the possibility of adopting a Soviet-type system in India, were Mahatma Gandhi, Nehru and Tagore. It would seem that, in their evaluation of Marxism-Leninism-Communism, all three categorically rejected the violent means of achieving a socialist system while, in essence, agreeing with its basic objectives.

Thus Gandhi wrote: 'I believe in non-violent ... communism.... if communism came without any violence, it would be welcome. For then no property would be held by anybody except on behalf of the pcoplc and for the people.' [Harijan, 13 February 1937, p. 45.] Again: 'What does communism mean in the last analysis? It means a classless society, an ideal that is worth striving for. Only I part company with it when force is called to aid for achieving it.' [Harijan, 13 March 1937, p. 152.] However, his reaction to the Bolshevik revolution and Soviet achievements was totally negative. Thus: 'India does not want Bolshevism.' [Young India, 1 May 1920, p. 18; Young India, 24 November 1921, p. 510.] Then again: 'As I look to Russia, where the apotheosis of industrialization has been reached, the life there does not appeal to me.... In modern terms, it is beneath human dignity to lose one's individuality and become a mere cog in the machine. I want every individual to become a fullblooded, full-developed member of the society.' [Harijan, 28 January 1939, p. 438.] It is not surprising that Soviet commentators under Stalin referred to him as a 'Hindu reactionary'.

As for Nehru, his reaction to the Russian revolution, after his visit to the Soviet Union in 1927, was euphoric: '.. if the future is full of hope, it is largely because of Soviet Russia and what it has done....' [Jawaharlal Nehru, Important Specches, Being a Collection of Most Significant Speeches Delivered by Jawaharlal Nehru from 1922 to 1946, edited by J. S. Bright (Lahore, 1946) p. 94.] Later on, there was a slight modification in his euphoria in view of the purge trials. While he believed the trials to be 'bona fide' to the extent that there was a 'definite conspiracy' against the Soviet government, he nonetheless admitted that the trials indicated 'ill health' in the Soviet body politic if it required the employment of such 'violence' as a remedy. [For details, see Jawaharlal. Nehru, From Lucknow to Tripura: A Survey of Congress Politics, p. 116.]

As for the actual adoption of a Soviet-type system in India, Nehru's attitude was negative both from the point of view of the method of implementing it and, also, its timing. Thus on the former issue, he wrote: 'In regard to the method and approach to this ideal, I may not agree with everything that the orthodox Communists have done. I think that these methods will have to adapt themselves to changing conditions and may vary in different countries...' [ As quoted in Subhas C. Bose, The Indian Struggle, 1920-34 (London: Wishart \& Co., 1934) p. 346.] On the issue of timing, he was more explicit: 'Much as I wish for the advancement to socialism in this country, I have no desire to force the issue in the Congress and 
thereby create difficulties in the way of our struggle for independence.' [Jawaharlal Nehru, Towards Freedom, Appendix, p. 402.] Also: '... the Congress stands today for full democracy in India and fights for a democratic state, not for socialism.' [ibid.]

3. In particular, Jawaharlal Nehru, who shaped India's socialist policy after independence, was greatly influenced by Fabian ideas which, in turn, were rooted in the traditions of English utilitarianism, empiricism and classical economic thought. English socialist tradition, in fact, was reformist from the beginning, in contrast to French socialism which was revolutionary. 'The decisive difference lay in the fact that the French Revolution had taught man to think in terms of seizing power.' [Cf. George Lichtheim, The Origins of Socialism (Frederick Praeger, 1969) p. 18.] The political counterpart of Fabian reformism was the adoption of a parliamentary, constitutional democracy for purposes of socialist legislation: indeed, as Nehru was to conceive of the appropriate political framework for India's transition to socialism.

It may however be noted that the reformist, gradualist political process was reinforced on the Indian scene also by the general rejection (already noted) of violence as a method of political action: this Gandhian preference for peaceful action, in turn, being rooted in Indian religious humanism.

4. The impact of English economic thinking on the Indian élite's attitude to governmental planning should not also be underestimated. At Cambridge (where most of the leading Indian economists were trained until studying in the United States became a viable option), the emphasis was typically on the inadequacy of the Invisible Hand, with little attention to how the Visible Hand system of intervention would operate in practice. Contrast this with the training of the Chicago economist where the failures of actual intervention are continually focused on and, in certain versions of the doctrine, even Benthamite intervention to preserve laissez-faire is considered unnecessary and/or counterproductive.

5. Thus, in the Second Five-year Plan, the share of the public sector in total investment was estimated at 54.0 per cent and it was planned at 58.6 per cent and 63.7 per cent in the Third and Fourth Mans respectively.

6. The resulting composition of public sector investment was heavily weighted towards steel, engineering, petroleum, chemicals, and mining and minerals, in that order.

7. We use the phrase 'Soviet example' quite deliberately. There is, in fact, little evidence that Soviet writings or Soviet political pressure had any significant impact on the thinking of Indian intellectuals or political parties or, more directly, on policy formulation. For a well-argued piece on this point, see Stephen Clarkson, "The low impact of Soviet writing and aid on Indian thinking and policy', Survey (1973) pp. $1-23$.
8. We may speculate that the shift to heavy industry was reinforced tangentially by Fabian influence as well. The Fabians had a rationalist faith in industry and science; and Nehru was to share it. His concern with modern technology and science was manifest in areas such as atomic energy and his acceptance of modern, heavy industry as part of India's economic programmes must therefore have been perfectly natural.

9. Details of this Act, and of the policy of industrial licensing as also target-setting, can be found in $\mathbf{J}$. Bhagwati and Padma Desai, India: Planning for Industrialization (London: Oxford University Press, 1970) especially chs. 12-14.

10. Of these three types of impact of the Soviet example, the Plan-formulation approach was to be enthusiastically received by most commentators and, indeed, to lead to demands on the part of aid agencies for similar efforts by other developing countries. However, the shift to heavy industry was seen as a definite mistake by economic opinion of the Chicagoschool variety, reflecting their basic unfamiliarity with the structural models of growth and development planning of the Feldman-Mahalanobis variety-an ignorance which probably still persists. The detailed regulation was not quite noticed at the time, except by conservative commentators whose position however was extreme and precluded governmental planning of industrial investments on any scale.

11. In fact, this is really how foreign aid advocates and agencies often estimated aid requirements. Cf. J. Bhagwati, Amount and Sharing of Aid (Washington, D.C.: Overseas Development Council, 1971) chapter V. For details on Indian planning models, as they evolved through the Plans, consult J. Bhagwati and S. Chakravarti, Contributions to Indian Economic Analysis, Supplement to American Economic Review (September 1970).

12. The decision to utilize foreign aid reflected, not merely the need to supplement domestic savings effort, but also a number of external factors favourable to the supply of aid to India. Thus, during the late $1950 \mathrm{~s}$, the aid climate was generally favourable, faith in India's development effort was running high and, against the background of the Cold War, Nehru's policy of non-alignment was effective in extracting aid from both the Western and Soviet-bloc donors.

13. As a proportion of NNP at factor cost, the utilization of external assistance by India was 2.37 in $1957-8,3.01$ in $1960-1,3.35$ in $1963-4,3.55$ in $1964-5,3.67$ in $1965-6$, and then fell substantially to $0.69,0.71,0.52$ and 0.48 in the next four years.

14. Commenting rather favourably on this aspect of Indian planning, William Lockwood writes: ‘. . . Yet it is of great human significance that India, for example, has doubled her food supplies since independence and left behind the great famines of history, that she has tripled the number of children in school until they 
now approach 100 million, that she has improved health care to the point where life expectancy at birth has risen from 35 to 52 , that her factories now provide her people with two million bicycles a year, that her newspaper press, one of the liveliest in the world, now reaches regularly some 20 million readers....' For details, see William W. Lockwood, 'Asian triangle: China, India, Japan', Foreign Affairs.

By contrast, K. N. Raj assesses the failures of this aspect of Indian planning in terms of the extent to which the public distribution system (in essential items such as food-grains) has reached the masses of the people. Thus at the end of December 1972, the population covered by statu tory rationing was only 16 million, mainly in the urban and semi-urban areas. Looking at the problem slightly differently, it would seem that whereas at least 20 per cent of the total consumption of food-grains in the country should be distributed statutorily to low-income groups, this magnitude was in the range of 12 to 13 per cent in the acute drought years of 1966 and 1967 . For details, see his 'Planning and prices in India', Centre for Development Studies, Trivandrum, March 1974, especially part II.

15. The evidence has been reviewed well by Pranab Bardhan in 'Redistribution with growth: some country experience: India', in $H$. Chenery, M. Ahluwalia, C. L. G. Bell, J. Duloy, and R. Jolly, Redistribution with Growth (Oxford University Press, 1974). However, the evidence is not conclusive in our judgement, and also excludes public consumption.

16. The detailed evidence in support of this conclusion has been discussed at great length in Bhagwati and Desai, op. cit., and has been further analysed in $J$. Bhagwati and T. N. Srinivasan, Foreign Trade Regimes and Economic Development: India, NBER (Columbia University Press, 1975, forthcoming). The political and social framework of the policies in this and the next paragraph have been discussed by $G$. Rosen, Democracy and Economic Change in India (University of California Press, 1966).

17. Nor have the Indian public sector enterprises been proof from pressures to use them for political purposes, e.g., to take on unsuitable or unnecessary staff; but there seems to be no evidence that this has been done on a systematic and crippling scale, as in Menderes' Turkey, for example, or significantly more than in the private sector in a society traditionally working on kinship and patronage principles.

18. Thus K. N. Raj, in 'What does socialism imply for economic policy in India now?', Mainstream (25 January 1964) has argued that: 'In the rural sector, land legislation since Independence has not made much difference to concentration in land ownership in the rural areas, and has in the main only induced the larger holders of land to either disguise the true position (by partitioning land among members of the same family, reporting tenants as attached labourers, etc.) or, in some cases, to take a more active interest in the cultivation of land in order to prevent the accrual of occupancy righ ts to others. The available data (such as those provided by the Planning Commission and the National Sample Survey) do not bring out adequately the extent of concentration in land ownership (both on account of the definitions of ownership adopted and the various methods of concealment open to owners at the stage of reporting). They also overstate the share of the larger units in "operated" (as distinguished from "owned") holdings, since the owners have an interest in reporting themselves as actual cultivators even when they depend really on sharecroppers for the cultivation of their land. In reality, therefore, ownership is much more concentrated, and cultivation takes place in much smaller units, than we are led to believe by these statistics. The slow progress of consolidation of plots (except in a few states) makes the actual cultivation units even more fragmented than would otherwise be the case.

19. However, there is some evidence to the contrary. Thus there is evidence that average real farm wages in the Punjab in 1967-9 were significantly above the pre-1966 average. Also, in Kerala and Madras, the two rice-growing states with the highest relative food-grain acreages of 17 and 14 per cent devoted respectively to the new varieties of rice, real wages of farm labour in 1967-9 have risen significantly over the 1954-66 average in comparison to other rice-growing states, where real farm wages declined. For details, see R. W. Herdt and E. A. Baker, 'Agricultural wages, production and high-yielding varieties', Economic and Political Weekly, Bombay, Vol. VII, No. 13, (25 March 1972). Also, it seems as if the disproportionate share of the larger farmers in cheap credit and fertilizers may reflect partly their greater ability to innovate with risk rather than their political power in the régime.

20. The English socialist tradition has been empiricalrationalist. Lichtheim notes that 'The British abandoned philosophical speculation in favour of an approach rooted in their non-traditional empiricism: the utilitarian doctrine, with its stress upon practical consequences and the "greatest happiness" of the greatest number.' [op.cit., p.12.]

By contrast, Marx rejected the utilitarian generalization that reasonable behaviour by individuals results in beneficial outcome for the community. In his judgement, the aggregate does not necessarily equal the sum of its elements and what is good for the individual could be determined only on the basis of an inquiry into the ultimate truth about history and society as well as man and nature. The inquiry which he undertook was a grand synthesis of philosophy, history and economics. In this fusion, historical reality proceeds from one stage to another in a dynamic but deterministic fashion as a result of continuous interaction between the material base of production and the ideological superstructure relevant to each stage. The ultimate and desirable stage is a classless society via a proletarian revolution. In their attempts at achieving this goal, Lenin and Mao further altered and refined the Marxist framework with endless discussions of what constitutes an objective revolutionary 
reality and who can be the agents of revolutions, of the distinction between 'spontaneity' and 'consciousness' and tactic and strategy, of the absolute prerequisite of classifying groups in terms of their class allegiance and so on.

All this, of course, was a far cry from the English socialist tradition which Nehru practised on the Indian scene.

21. This type of political economy could make a far greater contribution to the economic growth of a country in India's political predicament than any other single piece of economic research!

22. This ability to reverse ill-considered decisions is still one of the major assets of the present Indian régime. Albert Hirschman has argued that the failure to perceive progress may be the chicf obstacle to progress. One can improve on this witticism and say rather that the failure to perceive failure may be the chief obstacle to progress. 